\title{
COAGULATION DEFECTS IN LIVER DISEASE
}

\author{
BY \\ D. C. COWLING \\ From the Department of Pathology (Haematology), Postgraduate Medical School of London
}

(RECEIVED FOR PUBLICATION NOVEMBER 2, 1955)

By the introduction of the one-stage prothrombin test in 1935 Quick first devised a measure of the coagulation defect in liver disease (Quick, Stanley-Brown, and Bancroft, 1935). He subsequently (1938) pointed out that failure to absorb vitamin $\mathrm{K}$ in obstructive jaundice or failure to synthesize prothrombin in disease caused by parenchymatous liver-cell damage was the cause of the prolonged one-stage test.

Following the expansion of knowledge of the plasma factors required for normal haemostasis, Owren (1949) and Stefanini (1951a) have noted that in chronic liver disease there is a depression not only of true prothrombin but also of factor $\mathrm{V}$ and factor VII. Owren (1949) has drawn attention to the bad prognosis that may attend severe depression of factor $\mathrm{V}$ in hepatitis.

This paper presents the investigation of the haemostatic mechanism in a number of patients with liver disease.

\section{Methods}

The newer techniques were used, namely, the Quick one-stage test, giving the "Quick time" (Dacie, 1950); the prothrombin-consumption test (Merskey, 1950); the thromboplastin-generation test (Biggs and Douglas, 1953b) ; and the two-stage prothrombin test for estimation of "true" prothrombin (Biggs and Douglas, 1953a).

Factor $\mathrm{V}$ was assayed by a simplification of Stefanini's method (Stefanini, 1951b). Factor-V-deficient plasma was prepared by incubating oxalated plasma at $37^{\circ} \mathrm{C}$. for 36 to 48 hours. The "Quick time" of such a plasma is greatly prolonged and the shortening effect of the addition of freshly drawn standard normal plasma and the test plasma is shown in Fig. 1. From comparison of the shortening effect of the test plasma at various dilutions with the curve produced by adding dilutions of normal plasma the factor-V level may be assayed (see legend of Fig. 1 for further details).

Factor VII was estimated by a method similar to that for factor $V$, except that the ability of the test plasma, at various dilutions, was compared with that of a freshly drawn standard normal plasma to correct the deficiency of plasma freshly drawn from a patient on "tromexan" therapy. It is necessary that the prothrombin time of the patient's plasma should be markedly prolonged.

Antihaemophilic globulin and Christmas factor were assayed by a method based on the thromboplastingeneration test (Pitney, 1956).

Fibrinogen was not estimated quantitatively, but firm clots were always noted in the Quick one-stage test.

\section{Results}

Chronic Liver Disease.-In Table I are set out the results obtained in four representative patients with Laennec's cirrhosis of the post-hepatitis type who had reached the terminal stage of their disease. It also includes data from two patients with primary biliary cirrhosis as described by Sherlock (1955). The "Quick time" was prolonged in all the patients with Laennec's cirrhosis. It was influenced mainly by the deficiencies of

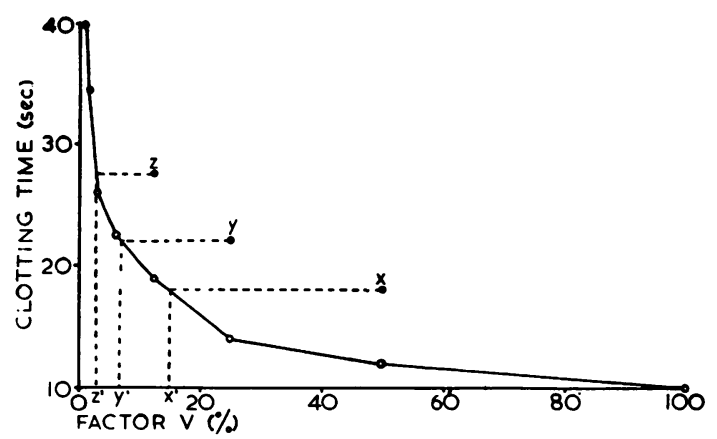

Fig. 1.-Example of factor $\mathrm{V}$ assay : varying quantities of fresh normal plasma are added to aged plasma and the prothrombin time of the mixture recorded (solid line). The percentage of factor $\mathbf{V}$ is taken to be equivalent to the percentage of fresh plasma added. The test plasma is substituted for the normal plasma and used in three dilutions, $50 \%, 25 \%$, and $12.5 \%$. The reading for $50 \%$ patient's plasma $(X)$ is 18 seconds $=15 \%$ of factor $V\left(X^{\prime}\right)$, hence $100 \%$ of patient's plasma would contain $30 \%$ of factor V. The reading for $25 \%$ of patient's plasma $(Y) \equiv 7 \%$ of factor $V\left(Y^{\prime}\right)$ hence $100 \%$ of patient's plasma $=28 \%$ of factor $\mathrm{V}$. The reading for $12.5 \%$ of patient's plasma $(Z) \equiv 3 \%$ of factor $V\left(Z^{\prime}\right)$, hence $100 \%$ of patient's plasma $=24 \%$ of factor $V$. The mean of the results obtained with $50 \%$ and $25 \%$ of patient's plasma is that usually recorded. 
TABLE I

SUMMARY OF INVESTIGATIONS ON PATIENTS WITH CIRRHOSIS OF THE LIVER

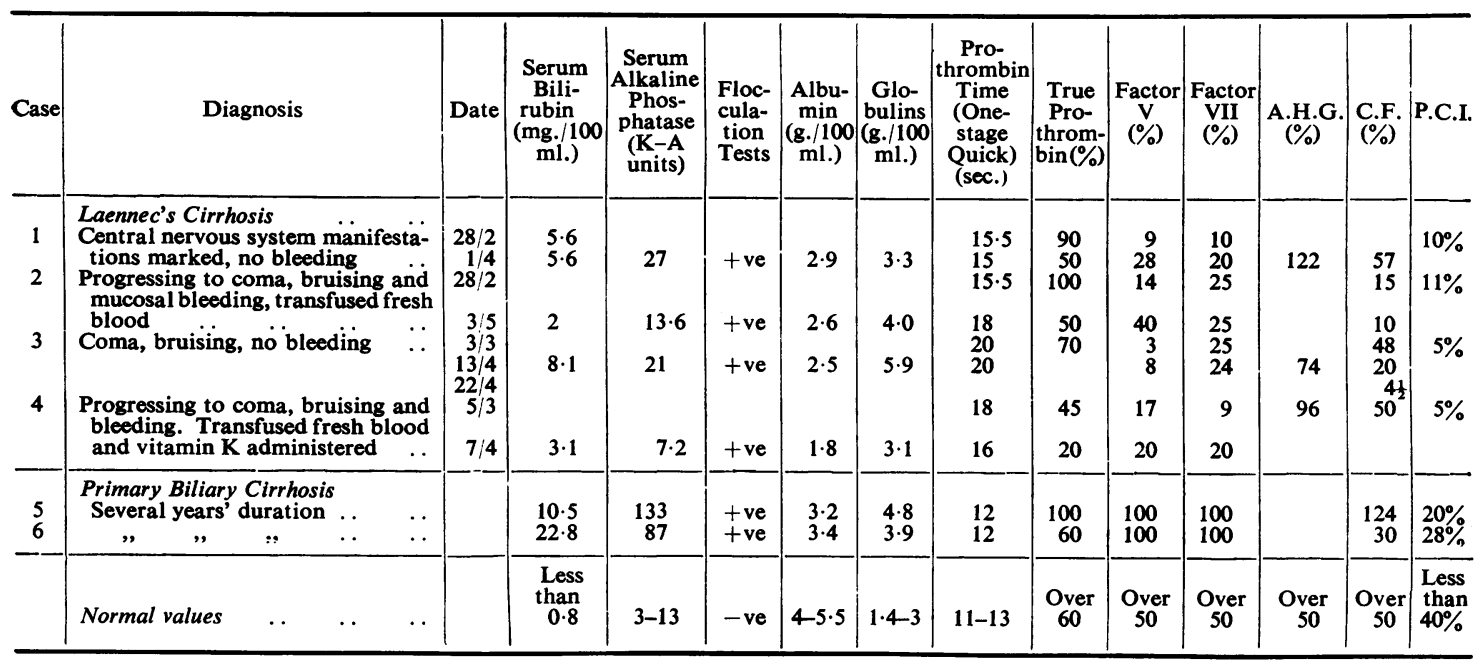

factor V and factor VII rather than of prothrombin itself. The antihaemophilic globulin concentration was within the normal range, but the Christmas factor activity was markedly reduced in two patients ; in Case 3 it was observed to fall as the patient's condition deteriorated.

The prothrombin consumption indices, performed at the time of the patient's first examination, were normal. Two patients had subnormal platelet counts, 84,000 per c.mm. (Case 3) and 100,000 per c.mm. (Case 1). Thromboplastin generation tests on patients with Laennec's cirrhosis showed that thromboplastin generation was impaired, using either the patient's plasma or serum in place of normal. The data obtained on Case 3 are shown in Table II.

TABLE II RESULTS OF THROMBOPLASTIN-GENERATION TEST ON CASE 3

\begin{tabular}{|c|c|c|c|c|c|c|c|c|}
\hline \multirow{2}{*}{$\begin{array}{c}\text { Aluminium } \\
\text { Hydroxide- } \\
\text { treated } \\
\text { Plasma }\end{array}$} & \multirow{2}{*}{ Platelets } & \multirow{2}{*}{ Serum } & \multicolumn{6}{|c|}{$\begin{array}{l}\text { Clotting Time of Subsamples } \\
\text { in Seconds }\end{array}$} \\
\hline & & & 1 & 2 & 3 & 4 & 5 & 6 \\
\hline $\begin{array}{c}\text { Case } 3 \\
\text {, } 3 \\
\text { Normal } \\
\text {," }\end{array}$ & $\begin{array}{c}\text { Normal } \\
\text {," } \\
\text {," }\end{array}$ & $\begin{array}{l}\text { Case 3 } \\
\text { Normal } \\
\text { Case 3 } \\
\text { Normal }\end{array}$ & $\begin{array}{l}90 \\
55 \\
55 \\
\end{array}$ & $\begin{array}{l}78 \\
45 \\
55 \\
27\end{array}$ & $\begin{array}{l}50 \\
25 \\
17 \\
13\end{array}$ & $\begin{array}{c}60 \\
20 \\
14 \cdot 5 \\
9\end{array}$ & $\begin{array}{c}45 \\
15 \\
13 \cdot 5 \\
11\end{array}$ & $\begin{array}{l}25 \\
16 \\
17 \\
11\end{array}$ \\
\hline
\end{tabular}

In contrast to the results in Laennec's cirrhosis, the two patients with primary biliary cirrhosis did not show gross disturbance of the plasma coagulation factors, apart from a lowering of Christmas factor in Case 6.
Portal Vein Thrombosis.-Two patients with portal-vein thrombosis, demonstrated by percutaneous transplenic portal venography, were investigated. Liver biopsies showed normal histology. In Case 7 the "Quick time" was prolonged and there was significant reduction of factors V and VII. The patient had suffered from haematemesis from oesophageal varices shortly before admission. After two weeks in hospital the coagulation defect improved, possibly as a result of recovery from the effects of the haemorrhage. In Case 8, with no history of bleeding, no disturbance of the plasma coagulation factors was noted (Table III).

Acute Hepatitis. - Two patients with acute hepatitis were investigated. Case 9 was suffering from infectious mononucleosis and Case 10 from hepatitis presumed to be viral in origin. Factor $\mathbf{V}$ was diminished during the acute stage of the disease in both patients. In Case 9 factor VII was reduced to $12 \%$ and the Quick time was prolonged. In this patient the coagulation tests became normal before the other biochemical tests and before clinical cure (Table III).

Obstructive Jaundice.-In two patients the Quick time was prolonged. In Case 11, in which jaundice had been present only a few days, factor VII alone was reduced. In Case 12, in which jaundice had been present for some weeks, factors $V$ and VII were both reduced.

Generalized Amyloid Disease with Liver Involvement.-Three patients with amyloid disease 
TABLE III

SUMMARY OF INVESTIGATIONS ON PATIENTS WITH PORTAL VEIN THROMBOSIS, ACUTE HEPATITIS, OBSTRUCTIVE JAUNDICE, AND OTHER CONDITIONS

\begin{tabular}{|c|c|c|c|c|c|c|c|c|c|c|c|c|c|}
\hline Case & Diagnosis & Date & $\begin{array}{c}\text { Bili- } \\
\text { rubin } \\
(\mathrm{mg} \% \%)\end{array}$ & $\begin{array}{c}\text { Alkaline } \\
\text { Phos- } \\
\text { phatase } \\
\text { (K-A } \\
\text { units) }\end{array}$ & $\begin{array}{l}\text { Floccu- } \\
\text { lation } \\
\text { Tests }\end{array}$ & $\begin{array}{c}\text { Albu- } \\
\text { min } \\
(\mathrm{g} . / 100 \\
\mathrm{m} 1 .)\end{array}$ & $\left|\begin{array}{c}\text { Glo- } \\
\text { bulins } \\
\text { (g./100 } \\
\text { ml.) }\end{array}\right|$ & $\begin{array}{l}\text { Quick } \\
\text { Pro- } \\
\text { throm- } \\
\text { bin }\end{array}$ & \begin{tabular}{|c|} 
True \\
Pro- \\
throm- \\
bin \\
Time \\
(sec.)
\end{tabular} & $\begin{array}{l}\text { Factor } \\
v \\
(\%)\end{array}$ & $\begin{array}{c}\text { Factor } \\
\text { VII } \\
(\%)\end{array}$ & $\underset{(\%)}{\text { A.H.G. }}$ & $\begin{array}{l}\text { C.F. } \\
\text { (\%) }\end{array}$ \\
\hline 7 & $\begin{array}{lll}\text { Portal Vein Thrombosis } & \ldots & \\
\text { Recent haematemesis } & . . & \ldots\end{array}$ & $22 / 3$ & $1 \cdot 1$ & 11.9 & $+\mathrm{ve}$ & 4.5 & 3.0 & $\begin{array}{l}18 \\
12 \cdot 5\end{array}$ & 90 & $\begin{array}{l}14 \\
56\end{array}$ & $\begin{array}{l}20 \\
60\end{array}$ & 200 & 76 \\
\hline 8 & Ascites & $7 / 4$ & 0.4 & 20.7 & $-v e$ & 2.5 & $4 \cdot 8$ & 11.9 & $\overline{80}$ & $\begin{array}{r}300 \\
100\end{array}$ & ${ }_{75}^{00}$ & 200 & 100 \\
\hline $\begin{array}{r}9 \\
10\end{array}$ & 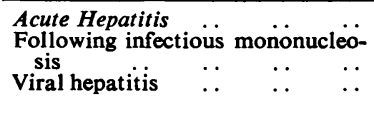 & $\begin{array}{r}7 / 4 \\
13 / 4 \\
17 / 3 \\
13 / 4\end{array}$ & $\begin{array}{l}5.9 \\
1.3 \\
7.7\end{array}$ & $\begin{array}{l}14 \cdot 7 \\
11 \cdot 4 \\
11\end{array}$ & $\begin{array}{l}+ \text { ve } \\
+ \text { ve } \\
+ \text { ve }\end{array}$ & $\begin{array}{l}4 \cdot 1 \\
3 \cdot 0\end{array}$ & $\begin{array}{l}3.6 \\
3.9\end{array}$ & $\begin{array}{l}15.1 \\
11.5 \\
13 \\
11.5\end{array}$ & $\begin{array}{r}80 \\
100 \\
80\end{array}$ & $\begin{array}{r}56 \\
100 \\
20 \\
76\end{array}$ & $\begin{array}{l}12 \\
100 \\
100 \\
100\end{array}$ & $\begin{array}{l}200 \\
134\end{array}$ & $\begin{array}{l}56 \\
64\end{array}$ \\
\hline $\begin{array}{l}11 \\
12\end{array}$ & 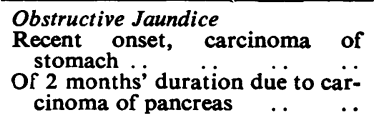 & & $\begin{array}{r}2 \cdot 8 \\
21 \cdot 0\end{array}$ & $\begin{array}{r}8 \\
86\end{array}$ & $\begin{array}{l}-\mathrm{ve} \\
-\mathrm{ve}\end{array}$ & $\begin{array}{l}3.0 \\
3.6\end{array}$ & $\begin{array}{l}3.9 \\
3.0\end{array}$ & $\begin{array}{l}15 \cdot 5 \\
15\end{array}$ & $\begin{array}{l}80 \\
60\end{array}$ & $\begin{array}{l}90 \\
12\end{array}$ & $\begin{array}{r}45 \\
8\end{array}$ & & 65 \\
\hline $\begin{array}{l}13 \\
14 \\
15\end{array}$ & $\begin{array}{l}\text { Amyloid Disease } \\
\text { Kidneys and liver, terminal muco- } \\
\text { sal haemorrhages } \\
\text { Liver and kidney, no bleeding } \ldots \\
\text { Liver and kidney and spleen, no } \\
\text { bleeding .. } \quad . . \\
\quad . .\end{array}$ & & 0.9 & $57 \cdot 7$ & $-\mathrm{ve}$ & $\begin{array}{l}0.8 \\
4.0 \\
2.4\end{array}$ & $\begin{array}{l}5.0 \\
4.4 \\
6.0\end{array}$ & $\begin{array}{l}21 \\
13 \\
32\end{array}$ & $\begin{array}{l}20 \\
60 \\
90\end{array}$ & $\begin{array}{l}85 \\
50 \\
62\end{array}$ & $\begin{array}{r}12 \\
100 \\
12\end{array}$ & $\mid \begin{array}{c}100 \\
\text { Normal }\end{array}$ & $\begin{array}{c}172 \\
\text { Normal }\end{array}$ \\
\hline
\end{tabular}

were investigated. In Case 13 , in which there were haemorrhagic manifestations before death, marked coagulation defects were present (Table III); the Quick time was prolonged and there were deficiencies of both prothrombin and factor VII. The prothrombin consumption index was abnormal (52\%, normal less than 40\%) and the coagulation time (Lee and White) was 12 minutes (normal 5-10 minutes). Christmas factor was assayed at $3 \%$. In Case 15 the Quick time was markedly prolonged, the Christmas factor was normal, and no bleeding occurred.

\section{Discussion}

Pathogenesis of Coagulation Factor Deficiencies in Liver Disease.-There are two mechanisms which may lead to deficiencies of coagulation factors in liver disease. The first is failure to absorb vitamin $\mathrm{K}$ which is necessary for the synthesis of factor VII, prothrombin, and possibly Christmas factor (Pitney, 1955). This is seen in its pure form in early uncomplicated cases of obstructive jaundice.

The second mechanism is abnormal synthesis of protein when the normal function of the liver parenchymal cells is impaired by disease. The results in cases of chronic liver disease indicate that factors V, VII, prothrombin, and Christmas factor are reduced, but not antihaemophilic globulin. The fact that antihaemophilic globulin is not diminished in parallel with the fall in other plasma factors indicates that this factor is syn- thesized elsewhere than in the liver. It is interesting to note that Graham, Collins, Godwin, and Brinkhous (1951) have shown that in severe liver damage in dogs the antihaemophilic globulin level remains normal although other plasma coagulation factors are deficient.

Cause of Bleeding in Patients.-It was noticed that, even when plasma coagulation factors were markedly reduced, bleeding did not always occur. The presence of thrombocytopenia, which is not infrequent in cases of liver disease, and of portal hypertension with oesophageal varices, are other factors influencing the development of bleeding in any particular case. The tests show that the plasma coagulation factors fluctuate rapidly in parallel with the clinical state of the patient. It is considered that the reduction of Christmas factor would significantly contribute to the occurrence of haemorrhage, for levels of up to $10 \%$ have been found in mild cases of Christmas disease (Pitney, 1955b).

Practical Investigation of Patients.-From these investigations it appears that a prolonged Quick time in liver disease is mainly caused by combined deficiencies of factors V and VII. Irrespective of what the test measures, it is useful, as deficiency of plasma coagulation factors, including Christmas factor, was only severe in those cases in which the Quick time was prolonged. The thromboplastin generation test is helpful in analysing the deficiencies further. However, as a serum defect in this test can be due to either factor VII or Christmas 
factor deficiency, it is necessary to assay them separately in liver disease. The bleeding time (Duke), coagulation time (Lee and White), and the prothrombin consumption index were normal in patients with cirrhosis when they were first examined, despite major deficiencies in coagulation factors. Thus the Quick one-stage test is the most reliable single test for assessing deficiency of plasma coagulation factors, and a markedly prolonged Quick time is a forewarning of possible bleeding. However, it is doubtful whether, even by assaying the known plasma coagulation factors individually, one may anticipate the onset of bleeding precisely.

\section{Summary}

Investigation of coagulation factors in liver disease has shown a complex pattern of deficiencies in which factor V, factor VII, and sometimes prothrombin are reduced in amount. Platelets are also not infrequently reduced in number.

It has been shown that the level of Christmas factor may also be markedly lowered in patients with severe liver damage, and it is considered that this deficiency contributes to the haemorrhagic state that may occur.

The concentration of antihaemophilic globulin remains normal in patients with severe liver damage.

\section{REFERENCES}

Biggs, R., and Douglas, A. S. (1953a). Journal of Clinical Pathology, 6, 15 . (1953b). Ibid., 6, 23.

Dacie, J. V. (1950). Practical Haematology. Churchill, London. Graham, J. B., Collins, D. L., Godwin, I. D., and Brinkhous, K. M. (1951). Proc. Soc. exp. Biol. (N.Y.), 77, 294.

Merskey, C. (1950). Journal of Clinical Pathology, 3, 130.

Owren, P. A. (1949). Scand. J. clin. Lab. Invest., 1, 131.

Pitney, W. R. (1956). Brit. J. Haematol., 2, 250.

- (1955). Personal communication.

Quick, A. J. (1938). J. Amer. med. Ass., 110, 1658. Stanley-Brown, M., and Bancroft, F. W. (1935). Amer. J. med. Sci., 190, 501 .

Sherlock, S. (1955). Diseases of the Liver and Biliary System. Blackwell, Oxford.

Stefanini, M. (1951a). Proceedings of the third International Congress of the International Society of Hematology, Cambridge, England, 1950, p. 484. Heinemann, London. (1951b). Lancet, 1, 606. 